\title{
19th Computed Maxillofacial Imaging Congress
}

Chairman: Allan G. Farman, PhD, DSc (USA) 